\title{
Chronic Treatment with Dopamine Receptor Antagonists: Behavioral and Pharmacologic Effects on $D_{1}$ and $D_{2}$ Dopamine Receptors
}

\author{
Ellen J. Hess, ${ }^{a}$ Andrew B. Norman, ${ }^{\mathrm{b}}$ and lan Creese \\ Center for Molecular and Behavioral Neuroscience, Rutgers, The State University of New Jersey, Newark, New Jersey \\ 07102
}

Rats were treated for $\mathbf{2 1} \mathrm{d}$ with the selective $D_{1}$ dopamine receptor antagonist $\mathrm{SCH} 23390$, the selective $\mathrm{D}_{2}$ dopamine receptor antagonist spiperone, the nonselective dopamine receptor antagonist cis-flupentixol, or a combination of SCH23390 and spiperone. In addition, a group of rats received L-prolyl-L-leucyl-glycinamide (PLG) for $5 \mathrm{~d}$ after the $21 \mathrm{~d}$ chronic spiperone treatment. Chronic treatment with $\mathrm{SCH} 23390$ resulted in a significant increase in $D_{1}$ dopamine receptor density with no change in the $D_{2}$ dopamine receptor density. Conversely, spiperone treatment resulted in a significant increase in $D_{2}$ dopamine receptors and no change in $D_{1}$ dopamine receptor density. PLG treatment had no effect. SCH23390 plus spiperone treatment resulted in a significant increase in both $D_{1}$ and $D_{2}$ dopamine receptor densities. However, although in vitro cis-flupentixol has an equal affinity for $D_{1}$ and $D_{2}$ dopamine receptors, only the $D_{2}$ dopamine receptor density increased after chronic treatment with cis-flupentixol.

In vivo treatment with the protein-modifying reagent $N$-ethoxycarbonyl-2-ethoxy-1,2-dihydroquinoline (EEDQ), which irreversibly inactivates $D_{1}$ and $D_{2}$ dopamine receptors, was used to investigate the paradoxical, selective $D_{2}$ dopamine receptor up-regulation induced by cis-flupentixol treatment. In vivo treatment with cis-flupentixol before EEDQ administration prevented the $D_{1}$ and $D_{2}$ dopamine receptor reductions induced by EEDQ. However, cis-flupentixol protected, in a dose-dependent manner, a greater percentage of $D_{2}$ dopamine receptors than of $D_{1}$ dopamine receptors from EEDQ-induced modification. These data indicate that, in vivo, cis-flupentixol preferentially interacts with $D_{2}$ dopamine receptors and could explain why only $D_{2}$ dopamine receptors were up-regulated following chronic treatment with cis-flupentixol.

Rats were tested for their cataleptic response to the ad-

Received May 27, 1987; revised Oct. 26, 1987; accepted Oct. 30, 1987.

This investigation was supported by NIMH Grant MH 32990, an RSDA MH 00316 (to I.C.), an NIMH predoctoral fellowship MH09535 (to E.J.H.) and the Scottish Rite Schizophrenia Research Program, NMJ, USA. The authors would like to thank Dr. George Koob for discussions and help with statistical analyses. We also thank Paula Martin and Christine Strand for manuscript preparation and Andrew Chen, Patricia Newton, Lesley Su, and Diane Swick for technical assistance.

Correspondence should be addressed to Dr. Creese, Center for Molecular and Behavioral Neuroscience, Rutgers, The State University of New Jersey, 195 University Avenue, Newark, NJ 07102.

a Present address: Molccular Biology Building, Rescarch Institute of Scripps Clinic, 10666 N. Torrey Pines Road, La Jolla, CA 92037.

b Present address: Department of Psychiatry, Laboratory of Behavioral Neuroscience, University of Cincinnati, 231 Bethesda Ave., Cincinnati, OH 45267.

Copyright (C) 1988 Society for Neuroscience 0270-6474/88/072361-10\$02.00/0 ministered drug over the course of the chronic drug treatment. Catalepsy scores of rats receiving spiperone decreased over the course of treatment, with a significant reduction in catalepsy occurring by treatment day 5 . The profound catalepsy observed in rats receiving $\mathrm{SCH} 23390$ did not change over the $21 \mathrm{~d}$ of treatment. Rats receiving cisflupentixol demonstrated tolerance to its cataleptogenic effects, with a significant reduction in catalepsy observed by treatment day 7 . During the 3 week treatment, the time between drug injection and a full cataleptic response to cisflupentixol increased from 20 to 60 min, suggesting a tolerance to the $D_{2}$, but not $D_{1}$, dopamine receptor antagonism by cis-flupentixol. A group of rats treated with $\mathrm{SCH} 23390$ for $21 \mathrm{~d}$ received a final acute injection of spiperone on day 22. These rats were as tolerant to the cataleptogenic effects of spiperone as were those rats tested on day 21 of chronic spiperone treatment. Conversely, rats challenged with an acute dose of $\mathrm{SCH} 23390$ after $21 \mathrm{~d}$ spiperone treatment were profoundly cataleptic. Thus, $\mathrm{D}_{2}$ dopamine receptor up-regulation is not necessary for the development of behavioral tolerance to $D_{2}$ dopamine receptor antagonism, whereas behavioral tolerance to $D_{1}$ dopamine receptor antagonism was not observed in these studies in spite of a $D_{1}$ dopamine receptor up-regulation.

Two distinct dopamine receptor subtypes coexist in the CNS (Kebabian and Calne, 1979; Creese et al., 1983): $\mathrm{D}_{1}$ dopamine receptors mediate the stimulation of adenylate cyclase activity (Hyttel, 1978), while $\mathrm{D}_{2}$ dopamine receptors inhibit the activity of this enzyme (Stoof and Kebabian, 1981; Onali et al., 1984; Battaglia et al., 1985). Although many neuroleptics block both dopamine receptor subtypes, previous research has focused on the role of $D_{2}$ dopamine receptors in the mechanism of action of neuroleptic drugs. This was due primarily to the high correlation between the affinities of neuroleptic drugs at the $\mathrm{D}_{2}$ dopamine receptor and their clinical dosages as antipsychotic agents (Creese et al., 1976; Seeman et al., 1976). In addition, selective $D_{2}$ dopamine receptor antagonists such as sulpiride are antipsychotic. Investigations of the $D_{1}$ dopamine receptor were hampered because of the lack of compounds selective for this receptor.

Tardive dyskinesia is a major complication of long-term neuroleptic drug administration used in treating schizophrenia. This disorder is characterizcd by abnormal movements of the facial muscles, tongue, and extremities (for review, see Baldessarini and Tarsy, 1980). To provide an animal model of tardive dyskinesia, rodents have been chronically treated with neuroleptic 
drugs (Tarsy and Baldessarini, 1974). The chronic treatment of rodents with neuroleptics does not usually result in the obvious dyskinetic movements of tardive dyskinesia, but does result in an increased sensitivity to the motor stimulatory effects of dopamine agonists, accompanied by an increase in dopamine receptor density. For example, chronic treatment with the $D_{2}$ dopamine receptor-selective antagonist haloperidol results in an increase in $D_{2}$ dopamine receptor density (Burt et al., 1977). It has been suggested that "pharmacological" denervation of dopamine receptors occurs during chronic antagonist treatment, which results in the supersensitive response to subsequent agonist administration (Creese and Sibley, 1981).

In humans and in rodents, the acute administration of neuroleptics results in Parkinsonian or cataleptic extrapyramidal motor side effects, respectively. However, tolerance develops to the extrapyramidal side effects of the classic neuroleptics, such as haloperidol or spiperone, after several weeks of repeated administration (Klett and Caffey, 1972; Ezrin-Waters and Seeman, 1977; Hess et al., 1986a). Similar to the receptor subtype-selective up-rcgulation scen following chronic $\mathrm{D}_{2}$ dopamine receptor blockade, chronic treatment with the $\mathrm{D}_{1}$ dopamine receptor-selective antagonist $\mathrm{SCH} 23390$ leads to a selective up-regulation in $\mathrm{D}_{1}$ dopamine receptors (Creese and Chen, 1985). However, rats receiving chronic SCH23390 treatment demonstrate no tolerance to the cataleptogenic effects of this drug (Hess et al., 1986a). Paradoxially, long-term treatment with antagonists such as fluphenazine or flupentixol, which have equal affinities for the $\mathrm{D}_{1}$ and $\mathrm{D}_{2}$ dopamine receptors in vitro, has been reported to up-regulate only $\mathrm{D}_{2}$ dopamine receptors (Murugaiah et al., 1984; Mackenzie and Zigmond, 1985; Boyson et al., 1986). It is unclear whether tolerance develops to the cataleptogenic effects of the mixed $D_{1} / D_{2}$ dopamine receptor antagonists $(\mathrm{Mu}-$ rugaiah et al., 1984).

Because $D_{1}$ and $D_{2}$ dopamine receptors interact in the modulation of behavior (Arnt and Hyttel, 1985; Breese and Mueller, 1985; Molloy and Waddington, 1985; Hess et al., 1986a), it is possible that the simultaneous antagonism of $D_{1}$ and $D_{2}$ dopamine receptors by drugs such as flupentixol may modulate or prevent the predicted $\mathrm{D}_{1}$ dopamine receptor up-regulation. $\mathrm{Al}$ ternatively, the paradoxical effects of mixed $D_{1} / D_{2}$ dopamine receptor antagonists may be due to differences in the interactions of these drugs at $\mathrm{D}_{1}$ and $\mathrm{D}_{2}$ dopamine receptors in vivo. For example, $\mathrm{D}_{2}$ dopamine receptors may be situated in a manner that allows a more rapid drug equilibration and prolonged blockade in vivo.

In order to investigate these phenomena further, we have assessed the effects of chronic treatment with a variety of dopamine receptor antagonists on $D_{1}$ and $D_{2}$ dopamine receptor densities and have determined the time course of the cataleptogenic effects of these drugs throughout the chronic treatment regimen. We have also examined the dopamine receptor-blocking properties of the mixed $D_{1} / D_{2}$ dopamine receptor antagonist flupentixol at $\mathrm{D}_{1}$ and $\mathrm{D}_{2}$ dopamine receptors in vivo using the protein-modifying reagent $N$-ethoxycarbonyl-2-ethoxy-1,2-dihydroquinoline (EEDQ). Peripherally administered EEDQ has been shown to irreversibly inactivate a number of neurotransmitter receptors, including $\mathrm{D}_{2}$ (Hamblin and Creese, 1983; Norman et al., 1987) and $D_{1}$ (Hamblin and Creese, 1983; Hess et al., 1987a) dopamine receptors, $S_{2}$ serotonin (Battaglia et al., 1986), and $\alpha_{2}$-adrenergic receptors (Adler et al., 1985). EEDQinduced inactivation of these receptors appears to occur at the ligand-recognition site, as EEDQ-induced inactivation can be prevented by prior administration of receptor-selective antagonists (Meller et al., 1985; Battaglia et al., 1986; Hess et al., 1987a). Meller et al. (1985) have demonstrated that flupentixol administration prior to EEDQ administration will "protect" both $\mathrm{D}_{1}$ and $\mathrm{D}_{2}$ dopamine receptors from in vivo EEDQ-induced modification. We have examined the time course of the interaction of flupentixol at $\mathrm{D}_{1}$ and $\mathrm{D}_{2}$ dopamine receptors in vivo by assessing flupentixol protection of $\mathrm{D}_{1}$ and $\mathrm{D}_{2}$ dopamine receptors from EEDQ-induced inactivation.

Additionally, we have investigated the possible desensitizing effects of the compound L-prolyl-L-leucyl-glycinamide (PLG) on chronic neuroleptic-induced $\mathrm{D}_{2}$ dopamine receptor up-regulation. PLG is thought to be a hypothalamic factor that inhibits the release of melanocyte-stimulating hormone (MSH) from the pituitary (Nair et al., 1971). This tripeptide has been reported to reverse the increased $\mathrm{D}_{2}$ dopamine receptor density that occurs after chronic $\mathrm{D}_{2}$ dopamine receptor blockade in rats (Chiu et al., 1981, 1985). It has been suggested that PLG may be useful in ameliorating the symptoms of tardive dyskinesia in man (Bhargava, 1984).

\section{Materials and Methods}

Chronic drug treatment and behavioral testing. Male Sprague-Dawley rats (180 gm; Simonsen, Gilroy, CA) were maintained in group cages on ad lib food and water and a $12 \mathrm{hr}$ light/dark cycle (6 AM/6PM). Rats were injected daily (s.c.) for $21 \mathrm{~d}$ at $10 \mathrm{AM}$ with the following drugs dissolved in salinc and a minimal amount of $0.1 \mathrm{~N} \mathrm{HCl}(5.0 \mu \mathrm{l}$ $\mathrm{HCl} / \mathrm{ml}$ saline): $0.5 \mathrm{mg} / \mathrm{kg} \mathrm{SCH} 23390(n=12), 1 \mathrm{mg} / \mathrm{kg}$ cis-flupentixol $(n=6), 0.2 \mathrm{mg} / \mathrm{kg}$ spiperone $(n=12), 0.5 \mathrm{mg} / \mathrm{kg} \mathrm{SCH} 23390$ plus 0.2 $\mathrm{mg} / \mathrm{kg}$ spiperone $(n=6)$. In addition, 6 control rats were injected with the saline vehicle. Rats were tested on days $1,3,5,7,14$, and 21 for a cataleptic response to their administered drug. Also, on day 22 , half the group of chronic spiperone-treated animals were injected with $0.5 \mathrm{mg} /$ $\mathrm{kg} \mathrm{SCH} 23390$ and half the group of chronic SCH23390-treated animals were injected with $0.2 \mathrm{mg} / \mathrm{kg}$ spiperone and observed for cataleptic responses. To test for catalepsy, observations were made every $20 \mathrm{~min}$ for $2 \mathrm{hr}$ following drug injection. Rats were individually placed in a box $(20 \times 20 \times 30 \mathrm{~cm})$ with a small bar diagonally placed across one corner, $10 \mathrm{~cm}$ above the floor. The rat's front paws were placed on the bar and the time taken for the rat to remove both paws was measured, with a cutoff time of $120 \mathrm{sec}$ (Sanberg et al., 1984). Two days following final drug injection, the rats were killed by decapitation and their brains rapidly removed to chilled saline. The striata were dissected, frozen in liquid nitrogen, and stored (1-2 weeks) at $-70^{\circ} \mathrm{C}$ until radioligand binding assay. Those rats receiving an acute antagonist challenge on day 22 were not used in the radioligand binding assays.

To examine the effects of PLG on neuroleptic-induced $\mathrm{D}_{2}$ dopamine receptor up-regulation, rats were injected daily (s.c.) with saline $(n=$ 12) or $0.2 \mathrm{mg} / \mathrm{kg}$ spiperone $(n=12)$ for $21 \mathrm{~d}$. On the $5 \mathrm{~d}$ following this chronic treatment, half the rats receiving saline $(n=6)$ and spiperone $(n=6)$ treatment were administered saline (s.c.). The remaining 6 animals from each group were injected daily (s.c.) with $20 \mathrm{mg} / \mathrm{kg}$ PLG for $5 \mathrm{~d}$. Two days following final drug injection, rats were killed and striata dissected as described above.

Radioligand binding assays. ${ }^{3} \mathrm{H}-\mathrm{SCH} 23390$ saturation analyses to determine $D_{1}$ dopamine receptor density and ${ }^{3} \mathrm{H}$-spiperone saturation analyses, to determine $\mathrm{D}_{2}$ dopamine receptor density were performed in parallel in the striata of each rat. Flupentixol competitions for 0.25 $\mathrm{nm}{ }^{3} \mathrm{H}-\mathrm{SCH} 23390$ or $0.1 \mathrm{~nm}{ }^{3} \mathrm{H}$-spiperone were performed in parallel in control rat striata. Tissue from each animal was homogenized (Tekmar Tissumizer setting $7,10 \mathrm{sec}$ ) individually in 40 volumes of ice-cold $50 \mathrm{~mm}$ Tris- $\mathrm{HCl}\left(\mathrm{pH} 7.4\right.$ at $\left.37^{\circ} \mathrm{C}\right)$. The tissue was centrifuged $(35,000 \times$ $\mathrm{g}, 10 \mathrm{~min}$ ) and washed once more in the same buffer, followed by a final resuspension in assay buffer consisting of $50 \mathrm{mM}$ Tris- $\mathrm{HCl}(\mathrm{pH} 7.4$ at $37^{\circ} \mathrm{C}$, $5 \mathrm{mM} \mathrm{MgSO}_{4}$, and $0.5 \mathrm{~mm}$ EDTA. Incubations for each radioligand were initiated by adding tissue ( $2 \mathrm{mg}$ wet weight tissue/tube) to duplicate tubes containing ${ }^{3} \mathrm{H}$-antagonists to yield a $2.5 \mathrm{ml}$ final assay volume. All saturation analyses included 6 concentrations of radioligand. Competition and saturation studies of ${ }^{3} \mathrm{H}-\mathrm{SCH} 23390(0.125-2$ $\mathrm{nM}$ ) were conducted in the presence or absence of $100 \mathrm{nM}$ cis-flupentixol 


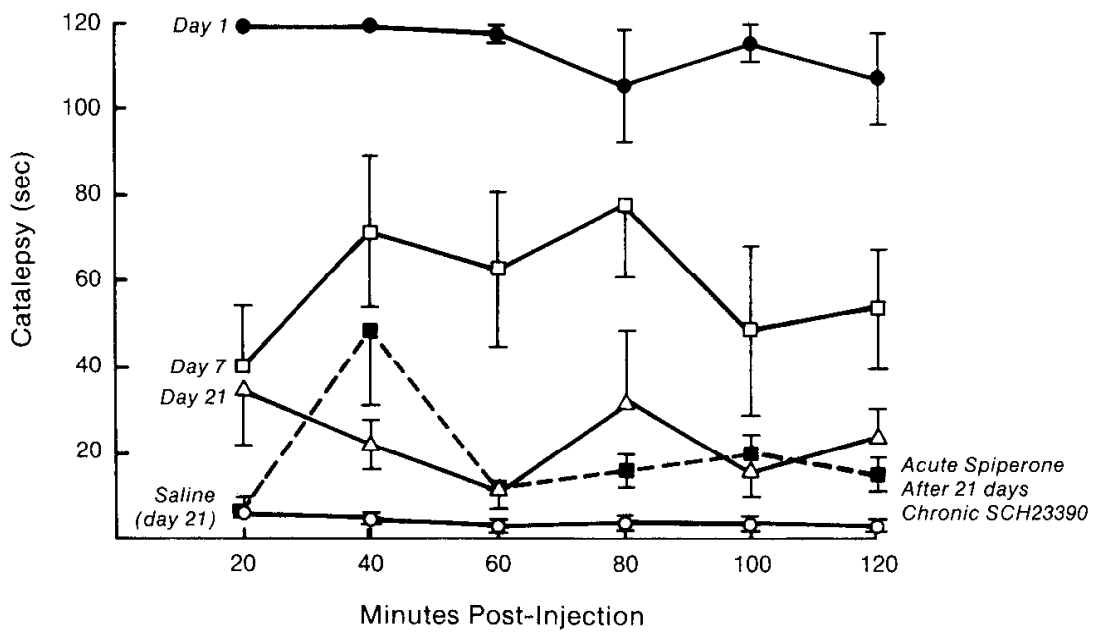

Figure 1. Cataleptic response of rats treated chronically with spiperone $(n=$ 6 ) or saline $(n=6)$. Spiperone treatment days 1,7 , and 21 , and saline treatment day 21 are presented. Additionally, data from rats treated with $\mathrm{SCH} 23390$ for $21 \mathrm{~d}$ and then challenged with an acute injection of spiperone on day 22 are presented $(n=6)$. All drug-treated rats were significantly more cataleptic than saline-treated rats on all testing days $(p<0.001)$. Catalepsy scores on days 7 and 21 of spiperone treatment and acute spiperone challenge after chronic SCH23390 treatment were significantly lower than scores on spiperone treatment day $1(p<0.001)$. Catalepsy scores from acute spiperone challenge after chronic SCH23390 treatment did not differ significantly from those after day 21 of spiperone treatment. Data represent means $\pm S E M$, with a maximum catalepsy score cutoff of $120 \mathrm{sec}$. in order to distinguish the specific from nonspecific binding. All ${ }^{3} \mathrm{H}-$ spiperone assays $(0.025-4 \mathrm{nM})$ were conducted in the presence of $40 \mathrm{nM}$ ketanserin to preclude binding of ${ }^{3} \mathrm{H}$-spiperone to $\mathrm{S}_{2}$ serotonin receptors; nonspecific binding was defined by $1 \mu \mathrm{M}(+)$ butaclamol. Competition experiments included 21 concentrations of flupentixol. Tubes were incubated for $40 \mathrm{~min}$ at $37^{\circ} \mathrm{C}$, filtered over Whatman $\mathrm{GF} / \mathrm{C}$ glass-fiber filters that were then washed rapidly with $15 \mathrm{ml}(3 \times 5 \mathrm{ml})$ of ice-cold Tris buffer and counted by scintillation spectroscopy at an efficiency of $50 \%$.

In vivo flupentixol specificity. Male Sprague-Dawley rats (160-180 $\mathrm{gm}$; Simonsen) were injected (i.p.) with $\mathrm{EEDQ}(8 \mathrm{mg} / \mathrm{kg})$ freshly dissolved in ethanol $/$ water $(1: 1 \mathrm{vol} / \mathrm{vol})$ or vehicle alone. To determine whether EEDQ had the same $\mathrm{EC}_{50}$ for $\mathrm{D}_{1}$ and $\mathrm{D}_{2}$ dopamine receptors, a dose-response for EEDQ was performed, in which rats received $1 \mathrm{mg}$ $\mathrm{kg}, 2 \mathrm{mg} / \mathrm{kg}$, or $4 \mathrm{mg} / \mathrm{kg}$ EEDQ. For protection experiments testing the specificity of flupentixol in vivo, rats were injected (s.c.) with $0.25,0.5$, 0.75 , or $1 \mathrm{mg} / \mathrm{kg}$ flupentixol dissolved in saline, or the saline vehicle $40 \mathrm{~min}$ before EEDQ $(8 \mathrm{mg} / \mathrm{kg})$ injection. Additionally, a second group of rats was injected with $0.5 \mathrm{mg} / \mathrm{kg}$ flupentixol or vehicle $20,40,60$, 80,100 , or $120 \mathrm{~min}$ prior to EEDQ $(8 \mathrm{mg} / \mathrm{kg})$ injection. Four hours after EEDQ treatment, rats were decapitated, the striata removed, frozen rapidly in liquid nitrogen, and stored $\left(-70^{\circ} \mathrm{C}\right)$ for $2-4$ weeks. Saturation analyses of ${ }^{3} \mathrm{H}$-antagonist binding were performed in the striata as described above, with the following tissue preparation to facilitate flupentixol washout: Tissue from each animal was individually homogenized in 40 volumes of ice-cold $50 \mathrm{~mm}$ Tris- $\mathrm{HCl}\left(\mathrm{pH} 7.4\right.$ at $\left.37^{\circ} \mathrm{C}\right)$. The tissue was centrifuged $(35,000 \times \mathrm{g}, 10 \mathrm{~min})$ and resuspended to $10 \mathrm{mg}$ tissue wet weight $/ \mathrm{ml}$ in this same buffer, followed by a $10 \mathrm{~min}$ incubation $\left(37^{\circ} \mathrm{C}\right)$. The incubation was stopped by the addition of $30 \mathrm{ml}$ ice-cold $50 \mathrm{~mm}$ Tris- $\mathrm{HCl}$. Tissue was centrifuged $(35,000 \times \mathrm{g}, 10 \mathrm{~min})$ and washed once more in this buffer, followed by a final resuspension in assay buffer consisting of $50 \mathrm{~mm}$ Tris- $\mathrm{HCl}\left(\mathrm{pH} 7.4\right.$ at $37^{\circ} \mathrm{C}$ ), $5 \mathrm{~mm} \mathrm{MgSO}_{4}$, and $0.5 \mathrm{~mm}$ EDTA. The saturation analyses were then completed as described above with ${ }^{3} \mathrm{H}-\mathrm{SCH} 23390$ and ${ }^{3} \mathrm{H}$-spiperone binding performed in parallel on striata from each rat.

Data analysis. ${ }^{3}$ II-Antagonist saturation data were analyzed by the method of Scatchard (1949). A weighted, nonlinear, least-squares curvefitting program, LIGAND (Munson and Rodbard, 1980) was used in the computer analysis of competition curves. All data were fitted while constraining the nonspecific binding parameter defined by $100 \mathrm{nM}$ cisflupentixol or $1 \mu \mathrm{M}(+)$ butaclamol. Data obtained in the catalepsytesting sessions were analyzed using arcsine transform analysis of variance with repeated measures and the Newman-Keuls test.

Materials. ${ }^{3} \mathrm{H}-\mathrm{SCH} 23390(87 \mathrm{Ci} / \mathrm{mmol})$ and ${ }^{3} \mathrm{H}$-spiperone $(88 \mathrm{Ci} /$ mmol) were obtained from Dupont-New England Nuclear (Boston, MA). EEDQ was obtained from Aldrich Chemical Co. (Milwaukee, WI), and L-prolyl-L-leucyl-glycinamide from Sigma Chemical Co. (St. Louis, $\mathrm{MO}$ ). The following drugs were generous gifts from the following sources: butaclamol, Ayerst Laboratories (Montreal, Canada); cis-flupentixol,
Dr. J. Hyttel of H. Lundbeck and Co. (Denmark); SCH23390, Drs. Iorio and Barnett of Schering Corp. (Bloomfield, NJ); spiroperidol, Dr. J. Leysen, Janssen Pharmaceutica (Beerse, Belgium). Other reagents were obtained from standard commercial sources.

\section{Results}

\section{Flupentixol competition for ${ }^{3} \mathrm{H}$-SCH23390 or ${ }^{3} \mathrm{H}$-spiperone binding}

Computer-fitted curves for cis-flupentixol competition for 0.25 nM ${ }^{3} \mathrm{H}-\mathrm{SCH} 23390$ binding modeled best to a single homogenous population of binding sites with a $K_{\mathrm{i}}$ of $0.69 \pm 0.01 \mathrm{nM}(n=$ 3). Computer-fitted curves for cis-flupentixol competition for $0.1 \mathrm{~nm}{ }^{3} \mathrm{H}$-spiperone binding modeled best to a single homogeneous population of binding sites with a $K_{\mathrm{i}}$ of $0.88 \pm 0.03$ $\mathrm{nM}(n=3)$. The affinity of flupentixol for $\mathrm{D}_{1}$ dopamine receptors was not significantly different from that of flupentixol for $D_{2}$ dopamine receptors $(p>0.05)$.

\section{Behavioral effects of chronic drug administration}

The overall catalepsy score, collapsed over each $2 \mathrm{hr}$ session of each daily treatment for rats treated with the $D_{2}$ dopamine receptor-specific antagonist spiperone, decreased over the course of the $21 \mathrm{~d}$ treatment (Fig. 1). A significant reduction in the overall catalepsy score recorded on day 1 of spiperone treatment occurred by day $5(p<0.01)$ and progressively increased over the $21 \mathrm{~d}$ period $(p<0.001)$. However, complete tolerance to the cataleptogenic effects of spiperone was not observed: the overall catalepsy score on testing day 21 of rats treated chronically with spiperone was significantly greater $(p<0.01)$ than the day 21 catalepsy scores of rats treated chronically with saline.

In contrast to the rats treated with spiperone (Fig. 1) and other classic neuroleptics, in which tolerance to their cataleptogenic effects develops after chronic treatment (Ezrin-Waters and Seeman, 1977), rats receiving chronic administration of the $D_{1}$ dopamine receptor-selective antagonist $\mathrm{SCH} 23390$ for $21 \mathrm{~d}$ demonstrated no tolerance to its cataleptogenic action over the $21 \mathrm{~d}$ administration $(p>0.05)$ (Fig. 2). The cataleptic effects of $\mathrm{SCH} 23390$ did diminish over the $2 \mathrm{hr}$ testing session, but the time course of this response did not change from that observed on day 1 over the $21 \mathrm{~d}$ treatment period. 


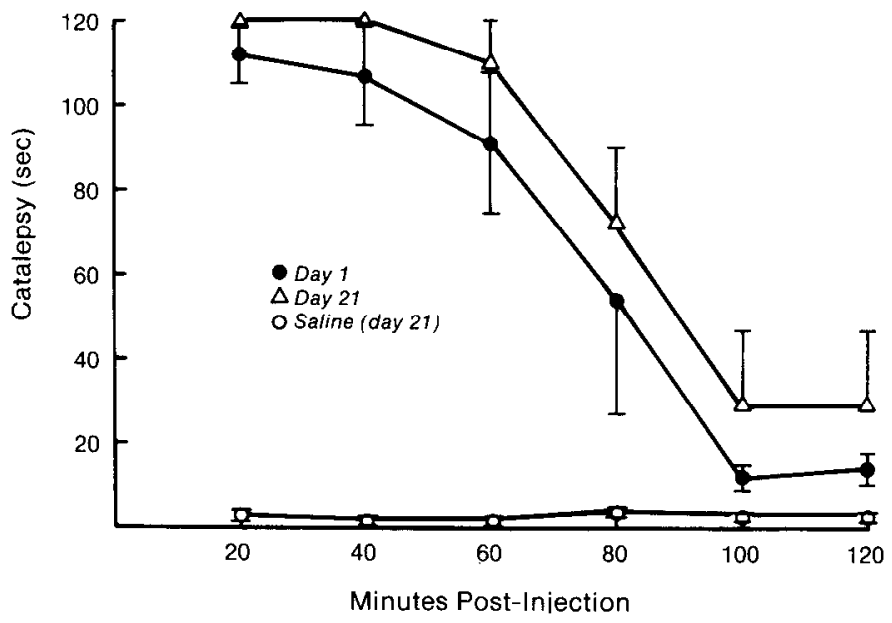

Figure 2. Cataleptic response of rats treated chronically with SCH23390 $(n=6)$ on days 1 and 21 of treatment, or saline $(n=6)$ on day 21 of treatment. SCH23390-treated rats were significantly more cataleptic than saline-treated rats $(p<0.001)$. The response to SCH23390 treatment did not change over the $21 \mathrm{~d}$ treatment regimen. Data represent means \pm SEM, with a maximum catalepsy score of 120 sec.

Rats receiving chronic administration of the mixed $D_{1} / D_{2}$ dopamine receptor antagonist flupentixol for $21 \mathrm{~d}$ demonstrated tolerance to its cataleptogenic action over the $21 \mathrm{~d}$ administration period, with a significant reduction $(p<0.01)$ in the overall catalepsy score collapsed over each $2 \mathrm{hr}$ session occurring by day 7 of treatment (Fig. 3). This was accompanied by a change in the pattern of catalepsy observed during the $2 \mathrm{hr}$ catalepsy scoring session over the duration of cis-flupentixol treatment. Over the 3 week treatment, in the first 60 min of the scoring session, these animals appeared to become significantly less catalcptic $(p<0.01)$ after cis-flupentixol administration. That is, the time between injection and a full cataleptogenic response to cis-flupentixol increased from 20 to 60 min over the $21 \mathrm{~d}$ administration period. In contrast, the pattern of catalepsy observed

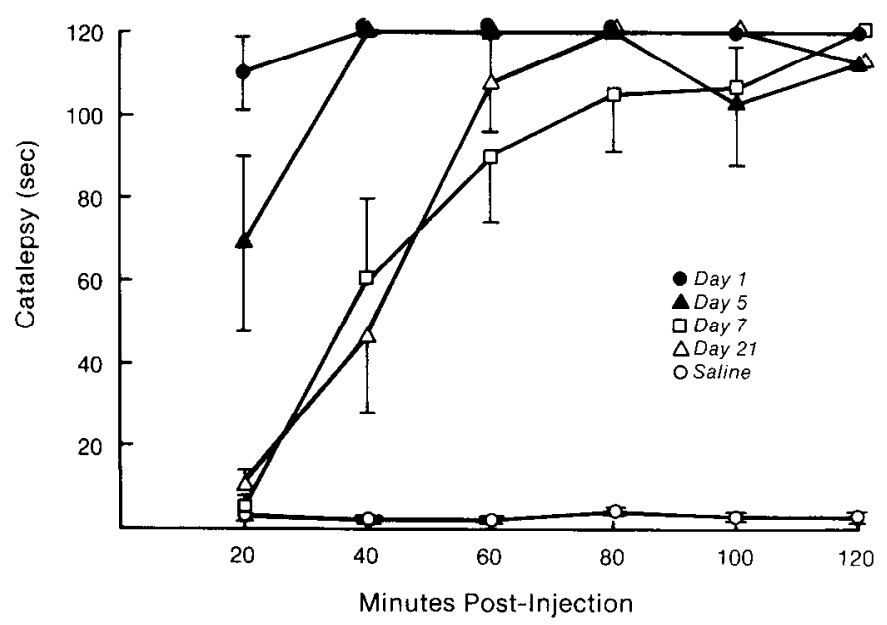

Figure 3. Cataleptic response of rats treated chronically with cis-flupentixol $(n=6)$ on days $1,5,7$, and 21 , or saline $(n=6)$ on day 21 . Flupentixol-treated rats were significantly more cataleptic than salinetreated rats on all days tested $(p<0.001)$. Catalepsy scores on days 7 and 21 were significantly lower $(p<0.01)$ than scores on day 1 , owing to a reduction in catalepsy scores at 20,40 , and $60 \mathrm{~min}$ after flupentixol injection $(n<0.05)$. Data represent means \pm SEM, with a maximum catalepsy score of $120 \mathrm{sec}$.

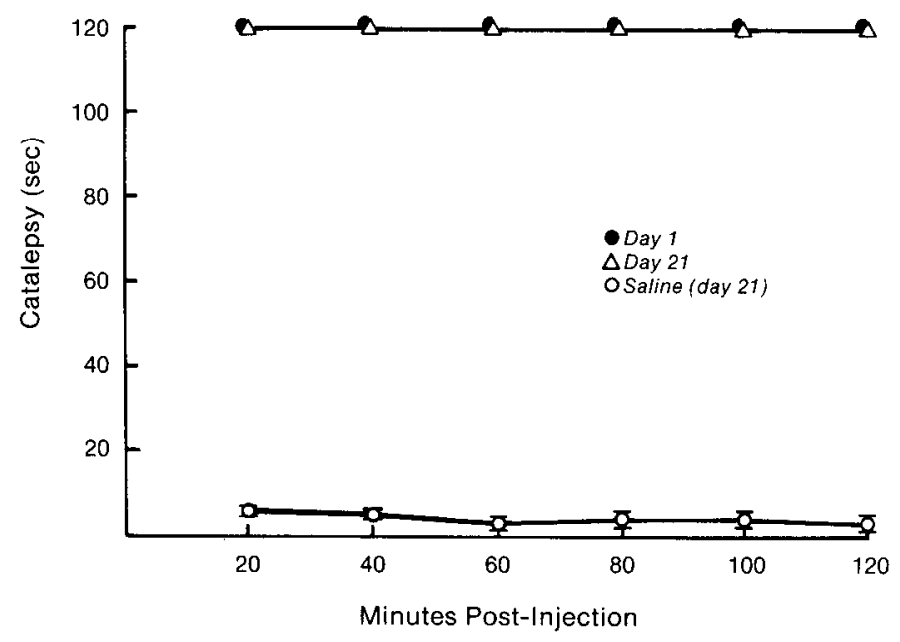

Figure 4. Cataleptic response of rats treated chronically with SCH23390 plus spiperone $(n=6)$ on days 1 and 21 of treatment, or saline $(n=6)$ on day 21 of treatment. SCH23390 plus spiperone-treated rats were significantly more cataleptic than saline-treated rats $(p<0.001)$. The response to $\mathrm{SCH} 23390$ plus spiperone treatment did not change over the $21 \mathrm{~d}$ treatment regimen. Data represent means $\pm S E M$, with a maximum catalepsy score of $120 \mathrm{sec}$.

over the $2 \mathrm{hr}$ catalepsy-scoring session did not change for the $21 \mathrm{~d}$ duration of either SCH 23390 or spiperone treatment. Those rats receiving $\mathrm{SCH} 23390$ plus spiperone demonstrated no tolerance to the cataleptic effect of this combination of $D_{1}$ and $D_{2}$ dopamine receptor antagonists (Fig. 4).

When rats were treated with $\mathrm{SCH} 23390$ for $21 \mathrm{~d}$ and then administered an acute injection of spiperone, tolerance to the cataleptogenic effects of spiperone was observed (Fig. 1). In fact, the catalepsy scores, collapsed over the $2 \mathrm{hr}$ session following acute challenge with spiperone after chronic $21 \mathrm{~d} \mathrm{SCH} 23390$ treatment, were not different $(p>0.05)$ from the scores of chronic spiperone-treated rats on spiperone injection day 21 . Conversely, rats challenged with an acute injection of SCH23390

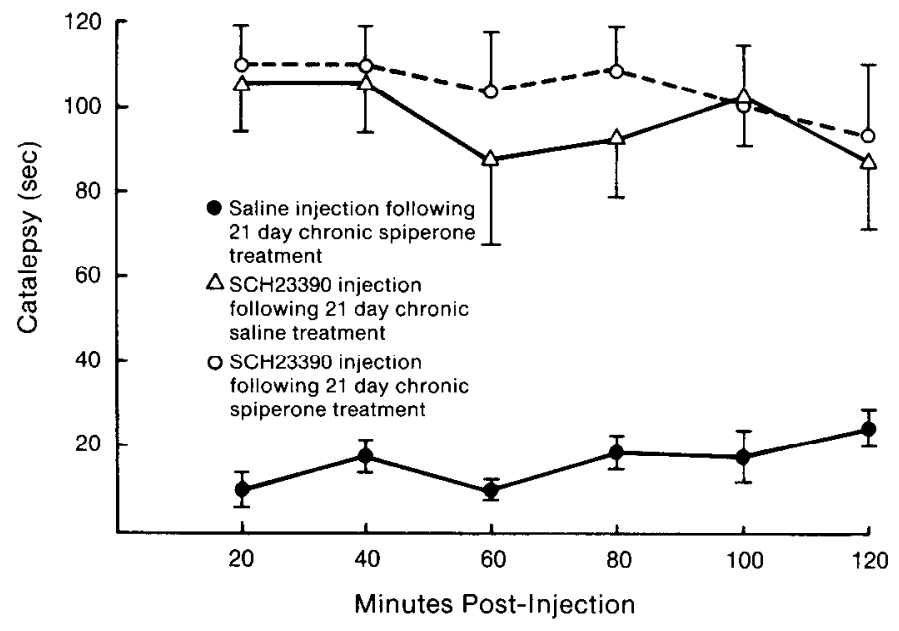

Figure 5. Cataleptic response of rats treated chronically with spiperone for $21 \mathrm{~d}$ and challenged with an acute injection of either saline $(n=6)$ or SCH23390 $(n=6)$ and rats treated with saline for 21 days and challenged with SCH23390. Catalepsy scores for a final SCH23390 injection were significantly greater than for the final saline injection $(p<0.001)$. Catalepsy scores for chronic $21 \mathrm{~d}$ spiperone treatment and chronic saline treatment with a final SCH23390 challenge did not differ significantly. Data represent means $\pm S E M$, with a maximum catalepsy score of $120 \mathrm{sec}$. 
Table 1. Effects of $21 \mathrm{~d}$ chronic drug treatments on striatal $D_{1}$ and $D_{2}$ dopamine receptor binding parameters

\begin{tabular}{|c|c|c|c|c|}
\hline \multirow[b]{2}{*}{$\begin{array}{l}\text { Chronic drug } \\
\text { treatment }\end{array}$} & \multicolumn{2}{|c|}{${ }^{3} \mathrm{H}-\mathrm{SCH} 23390$ binding } & \multicolumn{2}{|c|}{${ }^{3} \mathrm{H}-$ Spiperone binding } \\
\hline & $\begin{array}{l}B_{\max } \\
\text { (pmol/gm } \\
\text { tissue) }\end{array}$ & $\begin{array}{l}K_{\mathrm{d}} \\
(\mathrm{nM})\end{array}$ & $\begin{array}{l}B_{\max } \\
\text { (pmol/gm } \\
\text { tissue) }\end{array}$ & $\begin{array}{l}K_{\mathrm{d}} \\
(\mathrm{nM})\end{array}$ \\
\hline Control & $53.5 \pm 1.3$ & $0.44 \pm 0.03$ & $21.7 \pm 0.7$ & $0.08 \pm 0.01$ \\
\hline Flupentixol & $56.1 \pm 1.8$ & $0.44 \pm 0.03$ & $27.9 \pm 0.8^{* * *}$ & $0.10 \pm 0.01$ \\
\hline Spiperone & $54.7 \pm 1.7$ & $0.46 \pm 0.07$ & $26.8 \pm 0.6^{* * *}$ & $0.10 \pm 0.02$ \\
\hline SCH 23390 & $62.0 \pm 2.0^{*}$ & $0.41 \pm 0.01$ & $23.6 \pm 0.6$ & $0.08 \pm 0.01$ \\
\hline SCH23390 + spiperone & $63.6 \pm 2.2^{* *}$ & $0.46 \pm 0.01$ & $28.6 \pm 0.8^{* * * a}$ & $0.11 \pm 0.01$ \\
\hline
\end{tabular}

Data represent means \pm SEM $(n=6)$ for the affinities $\left(K_{d}\right)$ and densities $\left(B_{\max }\right)$ of $\mathrm{D}_{1}$ and $\mathrm{D}_{2}$ dopamine receptors, determined by saturation analyses of ${ }^{3} \mathrm{H}-\mathrm{SCH} 23390$ and ${ }^{3} \mathrm{H}$-spiperone binding, respectively. Rats were treated with cisflupentixol $(1 \mathrm{mg} / \mathrm{kg}$ per day), spiperone $(0.2 \mathrm{mg} / \mathrm{kg}$ per day $), S C H 23390(0.5 \mathrm{mg} / \mathrm{kg}$ per day) or spiperone $(0.2 \mathrm{mg} / \mathrm{kg}$ per day) plus SCH $23390\left(0.5 \mathrm{mg} / \mathrm{kg}\right.$ per day) for $21 \mathrm{~d}$. Asterisks denote values significantly greater than control values: ${ }^{*} p<$ $0.01,{ }^{* *} p<0.005,{ }^{* * *} p<0.001$

${ }^{a}$ SCH23390 plus spiperone value significantly greater than spiperone alone $(p<0.01)$; 1 -way ANOVA and Duncan's test.

after $21 \mathrm{~d}$ spiperone treatment were as profoundly cataleptic as rats that had received the $21 \mathrm{~d}$ chronic $\mathrm{SCH} 23390$ treatment (Fig. 5).

\section{Effect of chronic drug treatment on striatal dopamine receptor radioligand binding}

Consistent with previous reports by this laboratory (Creese and Chen, 1985; Hess et al., 1986a), chronic treatment with $\mathrm{SCH} 23390$ resulted in a highly significant increase $(+16 \%)$ in $\mathrm{D}_{1}$ dopamine receptor-specific ${ }^{3} \mathrm{H}-\mathrm{SCH} 23390$ binding $(p<0.01)$, but no significant change in $\mathrm{D}_{2}$ dopamine receptor-specific ${ }^{3} \mathrm{H}$ spiperone binding was observed $(p>0.05)$ (Table 1). Chronic treatment with the $\mathrm{D}_{2}$ dopamine receptor-selective antagonist spiperone resulted in a no significant change in ${ }^{3} \mathrm{H}-\mathrm{SCH} 23390$ binding ( $p>0.05)$, while ${ }^{3} \mathrm{H}$-spiperone binding was significantly increased by $24 \%(p<0.001)$ (Table 1$)$. Chronic treatment with $\mathrm{SCH} 23390$ plus spipcronc rcsulted in a significant increase in both ${ }^{3} \mathrm{H}-\mathrm{SCH} 23390(+19 \%)$ and ${ }^{3} \mathrm{H}$-spiperone binding $(+32 \%)$ (Table 1). The increase in ${ }^{3} \mathrm{H}$-spiperone binding in the animals treated with SCH23390 plus spiperone was significantly greater $(p<0.05)$ than that observed in ${ }^{3} \mathrm{H}$-spiperone binding in rats treated with spiperone alone. However, the increase observed in ${ }^{3} \mathrm{H}-\mathrm{SCH} 23390$ binding in rats treated with $\mathrm{SCH} 23390$ plus spiperone did not differ significantly from that in ${ }^{3} \mathrm{H}-\mathrm{SCH} 23390$ binding in rats treated with $\mathrm{SCH} 23390$ alone. Chronic treatment with the mixed $\mathrm{D}_{1} / \mathrm{D}_{2}$ dopamine receptor antagonist cis-flupentixol resulted in a significant increase in ${ }^{3} \mathrm{H}$-spiperone binding only $(+24 \%)(p<0.001)$, with no change observed in ${ }^{3} \mathrm{H}-$ SCH23390 binding (Table 1). The $K_{\mathrm{d}} \mathrm{s}$ of ${ }^{3} \mathrm{H}-\mathrm{SCH} 23390$ binding and of ${ }^{3} \mathrm{H}$-spiperone binding were unchanged by chronic drug treatment in any experimental condition (Table 1).

\section{Effects of PLG administration following $D_{2}$ dopamine receptor up-regulation}

The chronic $21 \mathrm{~d}$ spiperone treatment resulted in a significant $20 \%$ increase in ${ }^{3} \mathrm{H}$-spiperone binding $(p<0.01)$. Administration of PLG for $5 \mathrm{~d}$ following chronic spiperone treatment did not affect the antagonist-induced $\mathrm{D}_{2}$ dopamine receptor up-regulation (Table 2). In addition, $5 \mathrm{~d}$ PLG administration following $21 \mathrm{~d}$ saline treatment did not affect the $B_{\max }$ of the normosensitive $\mathrm{D}_{2}$ dopamine receptor population. In all treatments, the
$K_{\mathrm{d}}$ of ${ }^{3} \mathrm{H}$-spiperone binding was unchanged from control values (Table 2).

Effects of in vivo flupentixol pretreatment on EEDQ-induced reductions of $D_{1}$ and $D_{2}$ dopamine receptors

${ }^{3} \mathrm{H}-\mathrm{SCH} 23390$ and ${ }^{3} \mathrm{H}$-spiperone binding were markedly reduced by in vivo EEDQ treatment in a dose-dependent manner. In vivo $\mathrm{EEDQ}$-induced reductions in $\mathrm{D}_{1}$ and $\mathrm{D}_{2}$ dopamine receptors were comparable at all doses of EEDQ; EEDQ has an apparent $\mathrm{EC}_{50}$ of approximately $1.5 \mathrm{mg} / \mathrm{kg}$ (i.p.) for both the $\mathrm{D}_{1}$ and $\mathrm{D}_{2}$ dopamine receptors (Table 3 ). The magnitude of the EEDQ-induced reductions in $\mathrm{D}_{1}$ and $\mathrm{D}_{2}$ dopamine receptor binding could be reduced by treating rats with flupentixol before EEDQ administration. However, at all doses, flupentixol protected $\mathrm{D}_{2}$ dopamine receptor binding to a greater extent than it did $\mathrm{D}_{1}$ dopamine receptor binding when flupentixol was injected $40 \mathrm{~min}$ before $8 \mathrm{mg} / \mathrm{kg}$ EEDQ administration (Table 4). In fact, administration of $0.25 \mathrm{mg} / \mathrm{kg}$ flupentixol prior to EEDQ treatment protected $66 \%$ of $\mathrm{D}_{2}$ dopamine receptors, while only $21 \%$ of $\mathrm{D}_{1}$ dopamine receptors were protected by this dose. Admin-

Table 2. Effects of L-prolyl-L-leucyl-glycinamide (PLG) treatment on striatal $\mathrm{D}_{2}$ dopamine receptor binding after $21 \mathrm{~d}$ spiperone administration

\begin{tabular}{lll} 
Treatment (d) & $\begin{array}{l}B_{\max } \\
\text { (pmol/gm } \\
\text { tissue) }\end{array}$ & $\begin{array}{l}K_{\mathrm{dd}} \\
(\mathrm{nM})\end{array}$ \\
\hline $\begin{array}{l}\text { Saline (26) } \\
\begin{array}{l}\text { Saline (21) followed by PLG (5) } \\
\text { Spiperone (21) followed by } \\
\quad \text { saline (5) }\end{array}\end{array}$ & $21.7 \pm 0.5$ & $0.068 \pm 0.011$ \\
$\begin{array}{l}\text { Spiperone (21) followed by } \\
\text { PLG (5) }\end{array}$ & $26.13 \pm^{*}$ & $0.072 \pm 0.002$ \\
& $27.18 \pm 0.6^{* a}$ & $0.072 \pm 0.002$ \\
\end{tabular}

Data represent means $\pm \operatorname{SEM}(n=6)$ for the affinity $\left(K_{\mathrm{d}}\right)$ and density $\left(B_{\text {max }}\right)$ of $\mathrm{D}_{2}$ dopamine receptors, determined by saturation analyses of ${ }^{3} \mathrm{H}$-spiperone binding. Rats were treated with saline or spiperone $(0.2 \mathrm{mg} / \mathrm{kg})$ for $21 \mathrm{~d}$ and then treated with either saline or PLG $(20 \mathrm{mg} / \mathrm{kg})$ for the $5 \mathrm{~d}$ following chronic treatment. Asterisk denotes values significantly different from saline treatment $(p<0.01)$.

${ }^{a}$ Values not significantly different $(p>0.05)$ from comparable non-PLG-treated group. 
Table 3. Dose-dependent reductions in striatal $D_{1}$ and $D_{2}$ dopamine receptor binding after peripheral administration of EEDQ

\begin{tabular}{|c|c|c|c|c|}
\hline \multirow[b]{2}{*}{$\begin{array}{l}\text { EEDQs } \\
\text { dose }\end{array}$} & \multicolumn{2}{|c|}{${ }^{3} \mathrm{H}-\mathrm{SCH} 23390$ binding } & \multicolumn{2}{|c|}{${ }^{3} \mathrm{H}$-Spipcrone binding } \\
\hline & $\begin{array}{l}K_{\mathrm{d}} \\
\text { (nM) }\end{array}$ & $\begin{array}{l}B_{\max }(\% \text { reduction }) \\
(\mathrm{pmol} / \mathrm{gm} \text { tissue })\end{array}$ & $\begin{array}{l}K_{\mathrm{d}} \\
(\mathrm{nM})\end{array}$ & $\begin{array}{l}B_{\max }(\% \text { reduction }) \\
(\mathrm{pmol} / \mathrm{gm} \text { tissue })\end{array}$ \\
\hline Control & $0.47 \pm 0.02$ & $89.3 \pm 1.3$ & $0.095 \pm 0.005$ & $28.1 \pm 0.2$ \\
\hline $1 \mathrm{mg} / \mathrm{kg}$ & $0.48+0.02$ & $61.8+5.3(-31 \%)$ & $0.103 \pm 0.010$ & $20.2 \pm 1.6(-28 \%)$ \\
\hline $2 \mathrm{mg} / \mathrm{kg}$ & $0.51 \pm 0.02$ & $34.2 \pm 2.2(-62 \%)$ & $0.101 \pm 0.005$ & $11.5 \pm 0.7(-59 \%)$ \\
\hline $4 \mathrm{mg} / \mathrm{kg}$ & $0.49 \pm 0.05$ & $16.3 \pm 1.2(-82 \%)$ & $0.123 \pm 0.007$ & $6.6 \pm 0.3(-77 \%)$ \\
\hline
\end{tabular}

Data represent means $\pm \operatorname{SEM}(n=4-5)$ for affinities $\left(K_{\mathrm{d}}\right)$ and densities $\left(B_{\max }\right)$ of $\mathrm{D}_{1}$ and $\mathrm{D}_{2}$ dopamine receptors determined by ${ }^{3} \mathrm{H}-\mathrm{SCH} 23390$ and ${ }^{3} \mathrm{H}$-spiperone saturation analyses. Values in parentheses represent percentage loss of control receptor densities. Radioligand binding assays for both $D_{1}$ and $D_{2}$ dopamine receptors were performed in parallcl on tissuc from individual rats.

istration of $1 \mathrm{mg} / \mathrm{kg}$ flupentixol was necessary to achieve a degree of protection of the $D_{1}$ dopamine receptor comparable to that afforded the $\mathrm{D}_{2}$ dopamine receptor with $0.25 \mathrm{mg} / \mathrm{kg}$ flupentixol. A dose of $0.75 \mathrm{mg} / \mathrm{kg}$ flupentixol saturated the $\mathrm{D}_{2}$. dopamine receptor, since the degree of protection reached a plateau at this dose, with $86 \%$ of $\mathrm{D}_{2}$ dopamine receptors protected from irreversible modification by EEDQ. Because the flupentixol-dopamine receptor interaction is a reversible process, with some flupentixol free and some bound at any given instant, it is not surprising that $100 \%$ protection was never achieved, especially when using a close to saturating dose of EEDQ, as in these experiments.

To determine whether the differential protection was a timedependent phenomenon based on the accessibility of the drug to each dopamine receptor subtype (i.e., flupentixol had more rapid accessibility to $D$, dopamine receptors than to $D_{1}$ dopamine receptors in vivo), a time course of flupentixol protection of $\mathrm{D}_{1}$ and $\mathrm{D}_{2}$ dopamine receptors from EEDQ-induced inactivation was measured. Protection of $\mathrm{D}_{2}$ dopamine receptors by $0.5 \mathrm{mg} / \mathrm{kg}$ flupentixol was between 82 and $97 \%$ at all time points tested except the 20 min point, when flupentixol had probably not yet reached steady-state levels. The protection afforded $D_{1}$ dopamine receptors by flupentixol did not appear to differ from the time course of flupentixol protection of $D_{2}$ dopamine receptors within the time period that had been examined for the catalepsy measures. Maximal protection of $D_{1}$ dopamine receptors, which occurred $60 \mathrm{~min}$ after flupentixol administration, never exceeded $54 \%$ of control levels (Table 5). Furthermore, during the second hour of the experiment, protection of $D_{1}$ dopamine receptors declined to approximately $45 \%$, while pro- tection of $\mathrm{D}_{2}$ dopamine receptors was $\sim 97 \%$ during the second hour and had only declined to $82 \%$ protection at the $120 \mathrm{~min}$ point. In some instances, the $K_{\mathrm{d}}$ of ${ }^{3} \mathrm{H}-\mathrm{SCH} 23390$ and ${ }^{3} \mathrm{H}-\mathrm{spi}-$ perone binding was significantly greater than control values, presumably becausc of residual flupentixol remaining after the wash procedures, as EEDQ itself does not alter the affinity of ${ }^{3} \mathrm{H}-\mathrm{SCH} 23390$ or ${ }^{3} \mathrm{H}$-spiperone binding (Table 3 ).

\section{Discussion}

As we have previously reported (Creese and Chen, 1985; Hess et al., 1986a), chronic treatment with the $\mathrm{D}_{1}$ receptor-selective antagonist SCH23390 resulted in a significant and selective increase in the $\mathrm{D}_{1}$ dopamine receptor density. Likewise, consistent with previous reports, chronic treatment with the $\mathrm{D}_{2}$ dopamine receptor-selective antagonist spiperone selectively increased the $\mathrm{D}_{2}$ dopamine receptor density. However, chronic treatment with the mixed $D_{1} / D_{2}$ receptor antagonist flupentixol resulted in the up-regulation of $\mathrm{D}_{2}$ dopamine receptors only while the $\mathrm{D}_{1}$ dopamine receptor density was unchanged, consistent with previous reports (Murugaiah et al., 1984; Mackenzie and Zigmond, 1985). As we have demonstrated herein, flupentixol has comparable affinities for the $\mathrm{D}_{1}$ and $\mathrm{D}_{2}$ dopamine receptors in vitro. Since many investigators have reported an interaction between $D_{1}$ and $D_{2}$ dopamine receptors in the regulation of behavioral (Arnt and Hyttel, 1985; Molloy and Waddington, 1985; Breese and Mueller, 1985; Hess et al., 1986a) and electrophysiological (Carlson et al., 1987) responses, the lack of an increase in $D_{1}$ dopamine receptor density following chronic flupentixol treatment may be due to a modulatory receptor interaction occurring with concomitant $D_{1}$ and $D_{2}$ dopamine receptor blockade. To

Table 4. Effects of flupentixol pretreatment on in vivo EEDQ-induced reductions in striatal $D_{1}$ and $D_{2}$ dopamine receptor densities

\begin{tabular}{|c|c|c|c|c|}
\hline \multirow[b]{2}{*}{ Drug treatment } & \multicolumn{2}{|c|}{${ }^{3} \mathrm{H}-\mathrm{SCH} 23390$ binding } & \multicolumn{2}{|c|}{${ }^{3} \mathrm{H}$-Spiperone binding } \\
\hline & $\begin{array}{l}K_{\mathrm{d}} \\
(\mathrm{nM})\end{array}$ & $\begin{array}{l}B_{\max }(\% \text { protection }) \\
\text { (pmol/gm tissue) }\end{array}$ & $\begin{array}{l}K_{\mathrm{d}} \\
\text { (nM) }\end{array}$ & $\begin{array}{l}B_{\max }(\% \text { protection }) \\
\text { (pmol/gm tissue) }\end{array}$ \\
\hline Control & $0.42 \pm 0.05$ & $63.1 \pm 1.9$ & $0.06 \pm 0.003$ & $21.5 \pm 0.9$ \\
\hline EEDQ $(8 \mathrm{mg} / \mathrm{kg})$ & $0.53 \pm 0.04$ & $2.9 \pm 0.1^{* *}$ & $0.094 \perp 0.005$ & $1.3 \pm 0.1^{* *}$ \\
\hline Flupentixol $(0.25 \mathrm{mg} / \mathrm{kg})$ & $0.52 \pm 0.04$ & $15.4 \pm 1.3(21 \%)^{* *}$ & $0.10 \pm 0.005$ & $14.6 \pm 0.3(66 \%)^{* *}$ \\
\hline Flupentixol $(0.5 \mathrm{mg} / \mathrm{kg})$ & $0.72 \pm 0.08$ & $20.9 \pm 1.1(30 \%)^{* *}$ & $0.17 \pm 0.006$ & $17.6 \pm 2.3(81 \%)^{*}$ \\
\hline Flupentixol $(0.75 \mathrm{mg} / \mathrm{kg})$ & $0.68 \pm 0.05$ & $28.6 \pm 2.9(43 \%)^{* *}$ & $0.18 \pm 0.012$ & $18.7 \pm 1.3(86 \%)$ \\
\hline Flupentixol $(1 \mathrm{mg} / \mathrm{kg})$ & $0.72 \pm 0.06$ & $40.5 \pm 3.8(62 \%)^{* *}$ & $0.18 \pm 0.009$ & $18.6 \pm 0.9(86 \%)$ \\
\hline
\end{tabular}

Data represent means \pm SEM $(n=4-7)$ for affinities $\left(K_{\mathrm{d}}\right)$ and densities $\left(B_{\max }\right)$ of $\mathrm{D}_{1}$ and $\mathrm{D}_{2}$ dopamine receptors determined by ${ }^{3} \mathrm{H}$-SCH 23390 and ${ }^{3} \mathrm{H}$-spiperone saturation analyses. Values in parentheses represent percentage protection of the receptor-inactivating action of EEDQ by flupentixol, calculated using total receptors inactivated

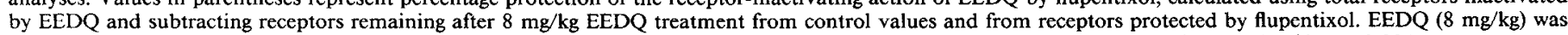
administered (i.p.) $40 \mathrm{~min}$ after flupentixol injection (s.c.). Asterisks represent values significantly lower than control values: ${ }^{*} p<0.05$, ${ }^{* *} p<0.001$. 
Table 5. Time course of flupentixol protection of striatal $D_{1}$ and $D_{2}$ dopamine receptors from EEDQinduced modification in vivo

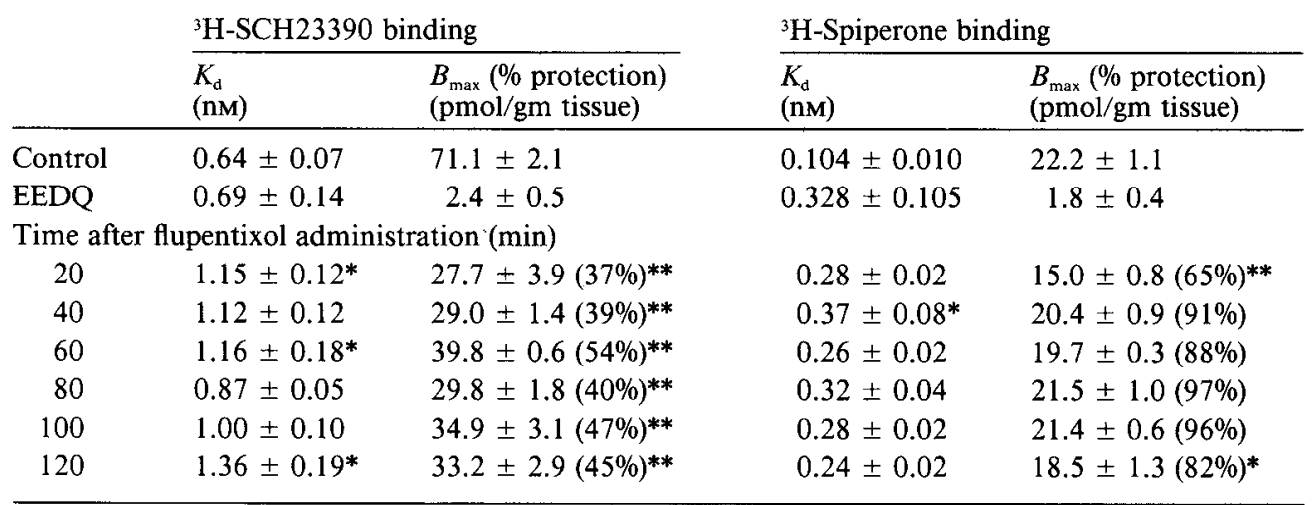

Data represent means $\pm \operatorname{SEM}(n=4-6)$ for affinities $\left(K_{\mathrm{d}}\right)$ and densities $\left(B_{\max }\right)$ of $\mathrm{D}_{1}$ and $\mathrm{D}_{2}$ dopamine receptors determined by ${ }^{3} \mathrm{H}$-SCH 23390 and ${ }^{3} \mathrm{H}$-spiperone saturation analyses. Values in parentheses represent percentage protection by flupentixol of EEDQ-induced receptor inactivation. EEDQ $(8 \mathrm{mg} / \mathrm{kg})$ was administered (i.p.) $20,40,60,80,100$, or 120 min after flupentixol injection $\left(0.5 \mathrm{mg} / \mathrm{kg}\right.$, s.c.). Asterisks indicate values significantly different from control values: ${ }^{*} p<0.05$, ** $p<0.01$.

test this hypothesis, rats received simultaneous treatment with a $\mathrm{D}_{1}$ receptor-selective antagonist $(\mathrm{SCH} 23390)$ and $\mathrm{D}_{2}$ dopamine receptor-selective antagonist (spiperone) to mimic the potential dual-receptor subtype-blocking activity of the mixed $\mathrm{D}_{1} / \mathrm{D}_{2}$ dopamine receptor antagonist flupentixol. Simultaneous $\mathrm{D}_{1}$ and $\mathrm{D}_{2}$ dopamine receptor antagonism resulted in an increase in the density of both $\mathrm{D}_{1}$ and $\mathrm{D}_{2}$ dopamine receptors using the drug doses employed in this study. Thus, simultaneous $D_{1}$ and $\mathrm{D}_{2}$ dopamine receptor antagonism does not appear to reduce the ability of $\mathrm{D}_{1}$ dopamine receptors to up-rcgulatc.

The increase in $\mathrm{D}_{2}$ dopamine receptors observed after $\mathrm{SCH} 23390$ plus spiperone treatment was significantly greater than the increase in $\mathrm{D}_{2}$ dopamine receptors after spiperone treatment alone. Thus, chronic blockage of $D_{1}$ dopamine receptors, which alone does not result in a statistically significant $\mathrm{D}_{2}$ dopamine receptor up-regulation, potentiated the $\mathrm{D}_{2}$ dopamine receptor up-regulation resulting from chronic $\mathrm{D}_{2}$ dopamine receptor blockade. Saller and Salama (1986) have recently demonstrated that $\mathrm{SCH} 23390$ reduces the in vivo increase in dopamine metabolites elicited by $\mathrm{D}_{2}$ dopamine receptor blockade. Thus, it is possible that the potentiation in $\mathrm{D}_{2}$ dopamine receptor up-regulation is due to a reduction in dopamine release onto $\mathrm{D}_{2}$ receptors caused by the $\mathrm{D}_{1}$ dopamine receptor blockade by $\mathrm{SCH} 23390$. The reduction in dopamine release would result in an effective increase in $\mathrm{D}_{2}$ dopamine receptor blockade by spiperone. Alternatively, another possibility is that the enhanced $\mathrm{D}_{2}$ dopamine receptor up-regulation after $\mathrm{SCH} 23390$ plus spiperone treatment may be the result of additional direct $\mathrm{D}_{2}$ dopamine receptor blockade by SCH23390. Although SCH23390 has minimal $\mathrm{D}_{2}$ dopamine receptor affinity in in vitro radioligand binding assays (Hess et al., 1986b), any small, additional direction $\mathrm{D}_{2}$ dopamine receptor blockade caused by $\mathrm{SCH} 23390$ in vivo (Stoof and Kebabian, 1981; Andersen and Nielsen, 1986) on top of the large blockade by spiperone may have been sufficient to induce the greater $D_{2}$ dopamine receptor up-regulation. Clearly, more extensive experimentation is necessary before this question can be answered.

An hypothesis to explain the differential effect of chronic flupentixol administration on $D_{1}$ and $D_{2}$ dopamine receptors is that, in contrast to its equal affinity at $D_{1}$ and $D_{2}$ dopamine receptors in vitro, in vivo flupentixol interacts differentially with
$D_{1}$ and $D_{2}$ dopamine receptors. Flupentixol protection of $D_{1}$ and $\mathrm{D}_{2}$ dopamine receptors from EEDQ-induced inactivation was used to test this hypothesis. To insure that EEDQ did not have a greater potency at $\mathrm{D}_{1}$ or $\mathrm{D}_{2}$ dopamine receptors in vivo, an EEDQ dose-response experiment assessing the effects of EEDQ on $\mathrm{D}_{1}$ and $\mathrm{D}_{2}$ dopamine receptors was performed: in vivo administration of EEDQ induced comparable percentage reductions in $\mathrm{D}_{1}$ and $\mathrm{D}_{2}$ dopamine receptors. That EEDQ induced equal reductions in $\mathrm{D}_{1}$ and $\mathrm{D}_{2}$ dopamine receptor binding at all doses administered in vivo is not surprising. The mechanism of action of EEDQ is thought to be due to the creation of highly reactive mixed carbonic anhydrides from carboxyl groups that, in turn, interact with nucleophilic groups such as free $\alpha$-amino groups (Belleau et al., 1968). EEDQ also has the capacity to modify enzymes such as serine proteases (Belleau et al., 1968) and adenylate cyclase (Hess et al., 1987a), in addition to neurotransmilter receptors. In fact, we have demonstrated that in vitro the carboxyl groups of the adenylate cyclase molecule appear to be as sensitive to EEDQ-induced alterations as those carboxyl groups modified at the $\mathrm{D}_{1}$ dopamine receptor. Thus, EEDQ-induced modifications seem to be dependent on the availability of carboxyl groups in a given protein. That is, EEDQinduced reductions in the $D_{1}$ and $D_{2}$ dopamine receptor density may be due to nonreceptor-specific carboxyl group modifications rather than to any specific "affinity" EEDQ might have for these receptors.

Since EEDQ induces comparable percentage reductions at $D_{1}$ and $\mathrm{D}_{2}$ dopamine receptors, it may be used as a tool to assess the relative interactions of drugs administered in vivo at these receptors. Treatment with flupentixol before the peripheral administration of EEDQ protected both $D_{1}$ and $D_{2}$ dopamine receptors from irreversible blockade by EEDQ, as previously demonstrated (Meller et al., 1985). However, at all doses of flupentixol tested and at all time points after flupentixol injection, flupentixol protected a greater percentage of $\mathrm{D}_{2}$ dopamine receptors than $\mathrm{D}_{1}$ dopamine receptors. That is, in vivo, flupentixol demonstrated a preference for the $\mathrm{D}_{2}$ dopamine receptor. The lipophilicity of flupentixol, which can result in free ligand depletion, could mask such a small, but functionally significant, difference in the determination of flupentixol affinities in vitro. Conversely, in vivo drug-receptor interactions, assessed from 
the use of drug treatment followed by EEDQ treatment, would reveal these small differences in affinity provided the drug was administered in a subsaturating dose. The in vivo procedure assesses relative drug interactions at 2 or more receptors simultaneously by measuring fractional occupancy. Thus, small differences in the affinity of a drug for 2 receptors would become obvious because fractional occupancy would never be equal at the different receptors, provided the drug is not at saturating concentrations for the examined receptors. Although this method of drug-induced protection from EEDQ-induced modification in vivo is not suitable for the quantitative determination of drug affinities at receptors, it should provide, with ease, a good reflection of relative drug interactions at specific receptors in vivo. These results are consistent with the results of P. H. Andersen (pcrsonal communication), who reports that when using in vivo radioligand binding for a direct quantitative assessment of in vivo receptor affinity, flupentixol in vivo has a higher affinity for $\mathrm{D}_{2}$ dopamine receptors than for $\mathrm{D}_{1}$ dopamine receptors. In our experiments, flupentixol appears to equilibrate at each dopamine receptor subtype within 40 min after injection, so the behavioral experiments were not confounded by any possible time-dependent differences in the accessibility of the drug to the receptor. Thus, it seems from these results, as well as from the report of $\mathrm{P}$. H. Andersen (personal communication), that chronic flupentixol treatment does not block a sufficient percentage of $D_{1}$ dopamine receptors to induce up-regulation. These results are noteworthy, as they demonstrate that, just as behavioral drug studies may not always provide an accurate assessment of specific drug-receptor interactions (e.g., the once-accepted hypothesis that apomorphine-induced stereotypies were due solely to $\mathrm{D}_{2}$ dopamine receptor activation), extrapolating specific in vivo drug-receptor interactions from in vitro radioligand binding data may be imprecise.

Twenty-one day chronic spiperone treatment, followed by 5 d PLG treatment, had no effect on the $\mathrm{D}_{2}$ dopamine receptor density. Previous studies (Bhargava, 1984; Chiu et al., 1985) have reported a PLG-induced reversal in the $\mathrm{D}_{2}$ dopamine receptor up-regulation following chronic neuroleptic treatment. Although the experiments described in those reports were fundamentally similar to the protocol described herein, those investigators administered haloperidol rather than spiperone; the difference in chronic drug treatment may account for the striking differences in the putative $\mathrm{D}_{2}$ dopamine receptor density-regulatory properties of PGL. PLG may also exert its regulatory effects, preventing neuroleptic-induced $\mathrm{D}_{2}$ dopamine receptor up-regulation, if it is administered prior to neuroleptic treatment, as previous reports have suggested (Chiu et al., 1981, 1985). Clearly, the prophylactic effects of PLG on dopamine receptor up-regulation require further examination.

As we have previously reported (Hess et al., 1986a), after chronic treatment with SCH 23390 for $21 \mathrm{~d}$, rats demonstrated no tolerance to the cataleptogenic effects of SCH23390. The decrease observed in the cataleptic response to SCH23390 over the $2 \mathrm{hr}$ testing session (Fig. 2) was probably due to rapid metabolism of the drug, rather than a tolerance phenomenon, since it was present on the first administration of the drug. It might be suggested that the prolonged catalepsy response to acute SCH23390 injection following 21 d chronic spiperone treatment results from a modulatory effect of the increased $D_{2}$ dopamine receptor density (compare Figs. 2 and 5). However, rats treated with saline for $21 \mathrm{~d}$ also demonstrated a prolonged catalepsy response to acute $\mathrm{SCH} 23390$ injection (Fig. 5). These results suggest that the differences observed in SCH23390-induced cat- alepsy over the $2 \mathrm{hr}$ testing sessions may reflect the behavioral variability seen when different groups of rats are tested on different days. In contrast to the pattern of catalepsy observed over the course of chronic SCH23390 treatment, rats became progressively tolerant to the cataleptic effects of spiperone; behavioral tolerance to these effects became obvious on trealment day 5 , and the rats became progressively more tolerant over the 21 d treatment period. Tolerance was not observed to the combination of SCH23390 plus spiperone, with maximal catalepsy scores recorded at all time points on all testing days. Rats treated chronically with flupentixol appeared to become less sensitive to the immediate cataleptic effects of this drug over the course of treatment, but continued to demonstrate profound catalepsy in the second hour after flupentixol administration. Since the EEDQ protection experiments indicated that flupentixol has a greater $D_{2}$ than $D_{1}$ dopamine receptor-blocking activity, it is possible that the behavioral tolerance to flupentixol observed during the first hour after drug administration is a reflection of the development of behavioral tolerance to the $\mathrm{D}_{2}$ dopamine receptor antagonism by flupentixol.

The discovery of antagonist drug-induced receptor up-regulation provided an altractive explanation for the behavioral tolerance to chronic antagonist administration (for review, see Creese and Sibley, 1981). However, the results described herein demonstrate that this mechanism cannot explain the tolerance or lack of tolerance of the cataleptic response to the chronic administration of dopamine receptor antagonists. It is not yet clear why rats become tolerant to the cataleptogenic effects of $\mathrm{D}_{2}$ dopamine receptor antagonists, but do not become tolerant to the $\mathrm{D}_{1}$ dopamine receptor antagonist $\mathrm{SCH} 23390$. Tolerance to chronic spiperone administration occurs concomitant with a $\mathrm{D}_{2}$ dopamine receptor up-regulation but does not occur to chronic $\mathrm{SCH} 23390$ administration in spite of a similar concomitant $\mathrm{D}_{1}$ dopamine receptor increase. Conversely, in spite of a normal complement of $\mathrm{D}_{2}$ dopamine receptors following chronic SCH23390 treatment, rats are just as tolerant to spiperone as they are following chronic spiperone administration. It is possible that in vivo SCII23390 may interact with $\mathrm{D}_{2}$ dopamine receptors to induce tolerance to an acute spiperone injection after chronic SCH23390 treatment. However, we have previously demonstrated that treatment with $\mathrm{SCH} 23390(0.5 \mathrm{mg} / \mathrm{kg}$, s.c.) before peripheral administration of EEDQ protects $D_{1}$ dopamine receptors from irreversible blockade by EEDQ, but that neither $\mathrm{D}_{2}$ nor $\mathrm{S}_{2}$ serotonin receptors were protected from EEDQinduced modifications by SCH23390 (Hess et al., 1986a). This indicates that SCH23390 at the dose administered in this study interacts in vivo exclusively with $\mathrm{D}_{1}$ dopamine receptors. Thus, behavioral tolerance to an acute injection of spiperone following 21 d chronic SCH23390 treatment is probably not due to any nonspecific effects of SCH23390 at the $\mathrm{D}_{2}$ dopamine receptor. It appears then that $\mathrm{D}_{2}$ dopamine receptor up-regulation is not necessary for the induction of behavioral tolerance. Although the $\mathrm{D}_{2}$ dopamine receptor recognition site may not be up-regulated, alterations in its second-messenger system may have occurred. For example, in a previous study we demonstrated that chronic SCH23390 treatment increased the ability of GTP to activate adenylate cyclase in rat striatal homogenate (Hess et al., 1986a).

Many studies have demonstrated that $D_{1}$ and $D_{2}$ dopamine receptors are interactive in their modulation of electrophysiological responses, as well as motor behavior. It has recently been suggested that drug-induced changes in the tonic electrical activity of the basal ganglia, particularly the globus pallidus, may 
reflect drug-induccd bchavioral effects (Carlson et al,, 1987). That is, agonist-induced increases in pallidal electrical activity seem to correlate approximately with agonist-induced increases in behavioral responses, while the converse is also true. Thus, an increase in $D_{1}$ dopamine receptors induced by chronic SCH23390 treatment may result in an overall increase in the tonic activity of the basal ganglia owing to the enhanced action of endogenous dopamine at the up-regulated $\mathrm{D}_{1}$ dopamine receptors. This overall activation imparted by increased $D_{1}$ dopamine receptor activity may be great enough to impart what appears to be behavioral tolerance to a $\mathrm{D}_{2}$ dopamine receptor antagonist essentially by "overriding" the $\mathrm{D}_{2}$ antagonist signal. These results parallel our earlier findings, where the behavioral effects of the $\mathrm{D}_{2}$ receptor agonist LY171555 were potentiated after a selective $D_{1}$ dopamine receptor up-regulation (Hess et al., 1986a). In fact, we have also previously demonstrated that after $D_{1}$ dopamine receptor up-regulation, rats exhibit an increase in spontaneous locomotor activity (Hess et al., 1986a). Following $\mathrm{D}_{2}$ dopamine receptor up-regulation, however, neither an increase nor decrease in spontaneous activity has been observed (Tarsy and Baldessarini, 1974). Thus, enhanced $D_{1}$ dopamine receptor stimulation following $D_{1}$ dopamine receptor up-regulation seems to promote an overall increase in activity levels, which may result from the enhanced effectiveness of endogenous dopamine at the up-regulated $D_{1}$ dopamine receptors. Conversely, $D_{2}$ dopamine receptor supersensitivity due to neuroleptic treatment is only apparent when the animal is challenged with a dopamaine receptor agonist. These results support the hypothesis (Barone et al., 1986; Waddington, 1986) that $D_{1}$ dopamine receptor activation may provide a tonic background activation that may be equated with an overall level of arousal. In this model, additional $\mathrm{D}_{2}$ dopamine receptor stimulation may be associated with the development of overt stereotyped behavior, which may be regulated by the level of $D_{1}$ dopamine receptor activation, with greater $D_{1}$ dopamine receptor activation yielding more intense agonist-induced $\mathrm{D}_{2}$ dopamine receptor-mediated stereotypy.

It has previously been suggested that the symptoms of schizophrenia may be due in part to "overactive" $D_{1}$ dopamine receptors (Memo et al., 1983; I Iess et al., 1987b). Hence, administration of an antipsychotic drug with a potent in vivo $\mathrm{D}_{1}$ dopamine receptor antagonist component may be beneficial in certain cases (Andersen et al., 1986). Such a mixed $D_{1} / D_{2}$ dopamine receptor antagonist would reduce what may be supranormal tonic activity by blocking $D_{1}$ dopamine receptors, while specific "stereotypical" symptoms would be controlled by the $\mathrm{D}_{2}$ dopamine receptor antagonist component. While many antipsychotic drugs have equal affinities at $\mathrm{D}_{1}$ and $\mathrm{D}_{2}$ dopamine receptors in vitro, it is not clear that these drugs are potent antagonists at $\mathrm{D}_{1}$ dopamine receptors in vivo, as exemplified by the flupentixol/EEDQ experiments presented herein. Because the 2 dopaminergic systems seem to interact in a synergistic manner (Braun et al., 1986; Waddington et al., 1986), it is possible that much lower doses of a drug having equal affinities at $\mathrm{D}_{1}$ and $\mathrm{D}_{2}$ dopamine receptors in vivo than a $\mathrm{D}_{2}$ dopamine receptor-sclectivc antagonist could be used to ameliorate the totality of schizophrenic symptoms, possibly reducing the subsequent incidence of tardive dyskinesia.

Tolerance develops to the extrapyramidal side effects of classic neuroleptics that act primarily at $\mathrm{D}_{2}$ dopamine receptors. However, since tolerance to the cataleptogenic effects of SCH23390 was not observed, chronic SCH23390 administration may induce unremitting Parkinsonian extrapyramidal side cffects in clinical trials. That tolerance to the cataleptogenicity of $\mathrm{SCH} 23390$ plus spiperone treatment was not observed in this study also suggests that a complete $D_{1}$ plus $D_{2}$ dopamine receptor blockade may also produce unremitting Parkinsonian side effects in the clinical setting. However, the doses of the drugs used in this study were rather high and the testing extended only over $21 \mathrm{~d}$. It would be useful to test treatments using lower doses of SCH23390 plus spiperone over a longer test period to determine whether the development of tolerance to the extrapyramidal side effects of stimultaneous $D_{1}$ and $D_{2}$ dopamine receptor blockade can occur.

\section{References}

Adler, C. H., E. Meller, and M. Goldstein (1985) Recovery of $\alpha$-adrenoceptor binding and function after irreversible inactivation by $\mathrm{N}$-ethoxycarbonyl-2-ethoxy-1,2-dihydroquinoline (EEDQ). Eur. J. Pharmacol. 116: 175-178.

Andersen, P.H. and E. B. Nielsen (1986) The benzazepine, SCH23390, inhibits ${ }^{3} \mathrm{H}-\mathrm{NPA}$ binding in mouse brain in vivo. Acta Pharmacol. Toxicol. 59: 315-318.

Andersen, P. H., E. B. Nielsen, F. C. Gronvald, and C. Braestrup (1986) Some atypical neuroleptics inhibit ${ }^{3} \mathrm{H}-\mathrm{SCH} 23390$ binding in vivo. Eur. J. Pharmacol. 120: 143-144.

Arnt, J., and J. Hyttel (1985) Differential involvement of dopamine D- 1 and D-2 antagonists of circling behavior induced by apomorphine, SK\&F 38393, pergolide and LY 171555 in 6-hydroxydopamine lesioned rats. Psychopharmacology $85: 346-352$.

Baldessarini, R. J., and D. Tarsy (1980) Dopamine and the pathophysiology of dyskinesias induced by antipsychotic drugs. Annu. Rev. Neurosci. 3: 23-41.

Barone, P., T. A. Davis, A. R. Braun, and T. N. Chase (1986) Dopaminergic mechanisms and motor function: Characterization of D-1 and D-2 receptor interactions. Eur. J. Pharmacol. 123: 109-114.

Battaglia, G., A. B. Norman, E. J. Hess, and I. Creese (1985) D-2 dopamine receptor-mediated inhibition of forskolin-stimulated adenylate cyclase activity in rat striatum. Neurosci. Lett. 59: 177-182.

Battaglia, G., A. B. Norman, P. L. Newton, and I. Creese (1986) In vitro and in vivo irreversible blockade of cortical $S_{2}$ serotonin receptors by $N$-ethoxycarbonyl-2-ethoxy-1,2-dihydroquinoline (EEDQ): A technique for investigating $S_{2}$ serotonin receptor recovery. J. Neurochem. 46: 589-593.

Belleau, B., V. Ditullio, and D. Godin (1968) The mechanism of irreversible adrenergic blockade by $N$-carbethoxydihydroquinolines: Model studies with typical serine hydrolases. Biochem. Pharmacol. 18: 1039-1044.

Bhargava, H. N. (1984) Enhanced striatal ${ }^{3} \mathrm{H}$-spiroperidol binding induced by chronic haloperidol treatment inhibited by peptides administered during the withdrawal phase. Life Sci. 34: 873-879.

Boyson, S. J., P. McGonigle, S. Reuter, D. Schambron, and P. B. Molinoff (1986) Quantitative autoradiography of D-1 and D-2 receptors following administration of neuroleptics. Soc. Neurosci. Abstr. 12: 192.

Braun, A. R., P. Barone, and T. N. Chase (1986) Interaction of $D_{1}$ and $D_{2}$ receptors in the expression of dopamine agonist induced behaviors. In Neurobiology of Central D,-Dopemine Receptors, I. Creese and G. R. Breese, eds., pp. 151-166, Plenum, New York.

Breese, G. R., and R. A. Mueller (1985) SCH-23390 antagonism of a D-2 dopamine agonist depends upon catecholaminergic neurons. Eur. J. Pharmacol. 113: 109-114.

Burt, D. R., I. Creese, and S. H. Snyder (1977) Antischizophrenic drugs: Chronic treatment elevates dopamine receptor binding in brain. Science 196: 326-328.

Carlson, J. H., D. A. Bergstrom, and J. R. Walters (1987) Stimulation of both $D_{1}$ and $D_{2}$ dopamine receptors appears necessary for full expression of postsynaptic effects of dopamine agonists: A neurophysiological study. Brain Res. 400: 205-216.

Chiu, P., G. Rajakumar, S. Chiu, R. L. Johnson, and R. K. Mishra (1985) Mesolimbic and striatal dopamine receptor supersensitivity: Prophylactic and reversal effects of L-prolyl-L-leucyl-glycinamide (PLG). Peptides 6: 183-189.

Chiu, S., C. S. Paulose, and R. K. Mishra (1981) Neuroleptic druginduced dopamine receptor supersensitivity: Antagonism by L-prolyl- 
L-leucyl-glycinamide. Science 214: 1261-1262.

Creese, I., and A. Chen (1985) Selective D-1 dopamine receptor increase following chronic treatment with SCH23390. Eur. J. Pharmacol. 109: 127-128.

Creese, I., and D. R. Sibley (1981) Receptor adaptations to centrally acting drugs. Annu. Rev. Pharmacol. Toxicol. 21: 357-391.

Creese, I., D. R. Burt, and S. H. Snyder (1976) Dopamine receptor binding predicts clinical and pharmacological potencies of antischizophrenic drugs. Science 192: 481-483.

Creese, I., D. R. Sibley, M. W. Hamblin, and S. Leff (1983) The classification of dopamine receptors: Relationship to radioligand binding. Annu. Rev. Neurosci. 6: 43-71.

Ezrin-Waters, C., and P. Seeman (1977) Tolerance to haloperidol catalepsy. Eur. J. Pharmacol. 41: 321-327.

Hamblin, M. W., and I. Creese (1983) Behavioral and radioligand binding evidence for irreversible dopamine receptor blockade by $\mathrm{N}$-ethoxycarbonyl-2-ethoxy-1,2-dihydroquinoline. Life Sci. 32: 22472255.

Hess, E. J., L. J. Albers, H. Le, and I. Creese. (1986a) Effects of chronic $\mathrm{SCH} 23390$ treatment on the biochemical and behavioral properties of $D_{1}$ and $D_{2}$ dopamine receptors: Potentiated behavioral responses to a $D_{2}$ dopamine agonist after selective $D_{1}$ dopamine receptor upregulation. J. Pharmacol. Exp. Ther. 238: 846-854.

Hess, E. J., G. Battaglia, A. B. Norman, L. C. Iorio, and I. Creese (1986b) Guanine nucleotide regulation of agonist interactions at $\left[{ }^{3} \mathrm{H}\right] \mathrm{SCH} 23390$ labeled $D_{1}$ dopamine receptors in rat striatum. Eur. J. Pharmacol. 121:31-38.

Hess, E. J., G. Battaglia, A. B. Norman, and I. Creese (1987a) Differential modification of striatal $D_{1}$ dopamine receptors and effector moieties by $N$-ethoxycarbonyl-2-ethoxy-1,2-dihydroquinoline (EEDQ) in vivo and in vitro. Mol. Pharmacol. 31: 50-57.

Hess, E. J., H. S. Bracha, J. E. Kleinman, and I. Creese (1987b) Dopamine receptor subtype imbalance in schizophrenia. Life Sci. 40: $1487-1497$.

Hyttel, J. (1978) Effects of neuroleptics on ${ }^{3} \mathrm{H}$-haloperidol and ${ }^{3} \mathrm{H}-$ cis(Z)-flupentixol binding and on adenylate cyclase activity in vitro. Life Sci. 23: 551-556.

Kebabian, J. W., and D. B. Calne (1979) Multiple receptors for dopamine. Nature 277: 93-96.

Klett, C. J., and E. Caffey (1972) Evaluating the long-term need of antiparkinson drugs by chronic schizophrenics. Arch. Gen. Psychiatry 26: 374-379.

Mackenzie, R. G., and M. J. Zigmond (1985) Chronic neuroleptic trcatment increases D-2 but not D-1 receptors in rat striatum. Eur. J. Pharmacol. 113: 159-165.

Meller, E., K. Bohmaker, M. Goldstein, and A. J. Friedhoff (1985) Inactivation of $\mathrm{D}_{1}$ and $\mathrm{D}_{2}$ dopamine receptors by $N$-ethoxycarbonyl2-ethoxy-1,2-dihydroquinoline in vivo: Selective protection by neuroleptics. J. Pharmacol. Exp. Ther. 233: 656-662.

Memo, M., J. E. Kleinman, and I. Hanbauer (1983) Coupling of dopamine $\mathrm{D}_{1}$ recognition sites with adenylate cyclase in nucleic accumbens and caudatus of schizophrenics. Science 221: 1302-1307.

Molloy, A. G., and J. L. Waddington (1985) Sniffing, rearing and locomotor responses to the D-1 dopamine agonist R-SKF 38393 and to apomorphine: Differential interactions with the selective D-1 and D-2 antagonists SCH 23390 and metaclopramide. Eur. J. Pharmacol. 108: 305-308.

Munson, P. J., and D. Robard (1980) LIGAND: A versatile computerized approach for characterization of ligand binding systems. Anal. Biochem. 107: 220-239.

Murugaiah, K., S. Fleminger, M. D. Hall, A. Theodorou, P. Jenner, and C. D. Marsden (1984) Alterations in different populations of striatal dopamine receptors produced by 18 months continous administration of cis- or trans-flupentixol to rats. Neuropharmacology 23: 599-609.

Nair, R. M. G., A. J. Kastin, and A. V. Schally (1971) Isolation and structure of hypothalamic MSH-release inhibiting hormone. Biochem. Biophys. Res. Commun. 43: 1375-1381.

Norman, A. B., G. Battaglia, and I. Creese (1987) Differential recovery rates of rat $D_{2}$ dopamine receptors as a function of aging and chronic reserpine treatment following irreversible modification: A key to receptor regulatory mechanisms. J. Neurosci. 7: 1484-1491.

Onali, P., M. C. Olianas, and G. L. Gessa (1984) Selective blockade of dopamine D-1 receptors by SCH23390 discloses striatal dopamine D-2 receptors mediating the inhibition of adenylate cyclase in rats. Eur. J. Pharmacol. 99: 127-128.

Saller, C. F., and A. I. Salama (1986) $D_{1}$ and $D_{2}$ dopamine receptor blockade: Interactive effects in vitro and in vivo. J. Pharmacol. Exp. Ther. 236: 714-720.

Sanberg, P. R., J. Pevsner, and J. T. Coyle (1984) Parametric influences on catalepsy. Psychopharmacology 82: 406-408.

Scatchard, G. (1949) The attraction of proteins for small molecules and ions. Annu. NY Acad. Sci. 51: 660-672.

Scatton, B. (1977) Differential regional development of tolerance to increases in dopamine turnover upon repeated neuroleptic administration. Eur. J. Pharmacol. 46: 363-369.

Seeman, P., T. Lee, M. Chau-Wong, and K. Wong (1976) Antipsychotic drug doses and neuroleptic/dopamine receptors. Nature 261: 717-719.

Stoof, J. C., and J. W. Kebabian (1981) Opposing roles for $\mathrm{D}_{1}$ and $\mathrm{D}_{2}$ dopamine receptors in efflux of cyclic AMP from rat striatum. Nature 294: $366-368$.

Tarsy, D., and J. Baldessarini (1974) Behavioral supersensitivity to apomorphine following chronic treatment with drugs which interfere with the synaptic function of catecholamines. Neuropharmacology 13: 927-940.

Waddington, J. L. (1986) Behavioural correlates of the action of selective D-1 dopamine receptor antagonists: Impact of SCH23390 and SKF83566, and functionally interactive D-1:D-2 receptor systems. Biochem. Pharmacol. 35: 3661-3667.

Waddington, J. L., A. G. Molloy, K. M. O’Boyle, and M. Mashurana (1986) Enantiomeric analogues of SCH23390 as new probes for behavioral interactions between $\mathrm{D}_{1}$ and $\mathrm{D}_{2}$ dopaminergic function. In Neurobiology of Central D,-Dopamine Receptors, I. Creese and G. R. Breese, eds., pp. 125-136, Plenum, New York. 